IdeAs

Idées d'Amériques

$4 \mid 2013$

Crises et effets de crise dans les Amériques

\title{
From Intrinsic to Radical Crisis in the United States : A Cultural Perspective
}

De la crise intrinsèque à la crise radicale en Amérique du nord: une lecture culturelle

De la crisis intrínseca a la crisis radical en América del norte : una lectura cultural

Jacques Pothier

\section{CpenEdition}

Journals

Édition électronique

URL : https://journals.openedition.org/ideas/715

DOI : $10.4000 /$ ideas.715

ISSN : 1950-5701

Éditeur

Institut des Amériques

Référence électronique

Jacques Pothier, «From Intrinsic to Radical Crisis in the United States: A Cultural Perspective », IdeAs [En ligne], 4 | 2013, mis en ligne le 15 octobre 2013, consulté le 18 octobre 2022. URL : http:// journals.openedition.org/ideas/715; DOI : https://doi.org/10.4000/ideas.715

Ce document a été généré automatiquement le 18 octobre 2022.

\section{cc) $(1) \ominus$}

Creative Commons - Attribution - Pas d'Utilisation Commerciale - Pas de Modification 4.0 International - CC BY-NC-ND 4.0

https://creativecommons.org/licenses/by-nc-nd/4.0/ 


\section{From Intrinsic to Radical Crisis in the United States : A Cultural Perspective}

De la crise intrinsèque à la crise radicale en Amérique du nord: une lecture culturelle

De la crisis intrínseca a la crisis radical en América del norte : una lectura cultural

Jacques Pothier

\section{NOTE DE L'ÉDITEUR}

Cet article a été traduit du français

\section{Cyclical crises, (re)foundational crises : Apocalyptic themes in American literature}

1 The cultural history of the United States is not a long and languid river. Nor, as Europeans might suggest with more than a touch of irony, is it a short and languid one, either. On the contrary, that history condenses a profusion of exploits and hardships within the very essence of its narrative. Without conceptualizing it in the same terms as does Edgar Morin when he speaks of "positive feedback », Americans have since before the foundation of the United States integrated into their thinking the idea that crises impose the necessary changes on society. The Puritans were quick to borrow from the Holy Writ in describing New England as the battlefield of an apocalyptic struggle between a chosen people and the devil's minions. At the close of the XVII ${ }^{\text {th }}$ century, corresponding to one of the particularly cold periods of the Little Ice Age, New England fell into an economic crisis. We know that this crisis resulted in social and 
economic tensions - and particularly in a generalized sense of fear - because the American settlers left records, notably the records of the Salem witch trials ${ }^{1}$. Since the crisis was seen as having come by divine providence, it became a means by which to renew the legitimacy of the religious colonizing mission and galvanize the population's at times unsteady Protestant faith to drive forward the project that had yet to be called the American Dream.

2 Thus, already in the XVII th century, the American preachers of New England seized on the difficulties of their colony in order to lay bare the anatomy of the prevailing crisis and surely the most illustrative example is the writings of the Puritan minister Cotton Mather. In his descriptions of the bloody witch trials carried out in Salem, Massachusetts, Mather dramatized the crisis as critical in the original Greek sense of the word - the moment of judgment, of the trial by ordeal, of the manifestation and the revelation of the eternal confrontation that he saw taking place in New England. The crisis was the paramount manifestation of the Scriptures, an incarnation of the Word of God that was then far from being called story-telling. Mather unfurled this vision in Magnalia Christi Americana (1702), his account of Christ's wondrous works in America. Indeed, he believed that at play was nothing less than the ultimate struggle between the forces of Satan, lying in wait on a godless continent, and those chosen by God to go into the New World where they would establish communities founded in a purified covenant with the everlasting. For Mather, the crisis became the paroxysm of the America-to-be : the temporality of the American adventure was bound up with crisis in permanence. This also became an opportunity to identify within the group elements who had fallen prey to external influences alien to the collective project. Thus the crisis was a time to reestablish a mission that had been forgotten, to denounce an America that seemed set to lose sight of its spiritual compass, an America that would not only no longer resemble its missionary vision, but that would in essence no longer be itself.

3 In his evocatively titled study, The Rites of Assent, Sacvan Bercovitch provides an analysis of the identity mechanisms at work in the classic American literature that followed the time of the Founding Fathers. American literature, in Bercovitch's reading, has the dual cultural and political function of establishing the rites of participation in the construction of the national myth, of membership in the alchemy that transubstantiates crises into foundational events that evoke revelation ${ }^{2}$. The American revolution was to be an occasion to relaunch the myth machine: flowing from Thomas Jefferson's pen, the Declaration of Independence was, for those who signed it, a document bestowing legitimacy on what they felt was their most pressing struggle. The revolutionaries justified themselves before the world by summoning the menace of moral and political chaos into which King George III's Great Britain threatened to plunge the American colonies. Thus the American "revolution », in fact, was to consist of a return to order. Importantly, the etymology of the word "revolution» was at the time heavily charged with recent advances made by astronomers and mathematicians, thus being rather more suggestive of circularity than it is today : the revolution was out to restore something that had been lost.

4 Eighty-seven years later, several months after the bloodiest battle in the recorded history of the continent, and perhaps of the Western world until that point, Abraham Lincoln gave voice to the same logic in his pronouncement during the inauguration of the Gettysburg National Cemetery, on November 19, 1863 : 
Four score and seven years ago our fathers brought forth on this continent a new nation, conceived in liberty and dedicated to the proposition that all men are created equal. [...]

It is for us the living rather to be dedicated here to the unfinished work which they who fought here have thus far so nobly advanced. It is rather for us to be here dedicated to the great task remaining before us-that from these honored dead we take increased devotion to that cause for which they gave the last full measure of devotion-that we here highly resolve that these dead shall not have died in vain, that this nation under God shall have a new birth of freedom, and that government of the people, by the people, for the people shall not perish from the earth. ${ }^{3}$.

After Gettysburg and, paradoxically, thanks to Gettysburg, says Lincoln, the nation divided shall unite around the ideological identity and political project that have now been reaffirmed - in other words, around its democratic ideals. The crisis is not a catastrophe that burst in from out of clear blue skies, as might a whim of nature. It is simply a moment of return. As Edgar Morin has shown, although crisis engenders anxiety and uncertainty, it is not a rupture of causal continuity, though it can occasion a rupture of our cognitive capacity to grasp that continuity - it is this rupture that intellectuals have a responsibility to prevent. In this view, the crisis refounds, the crisis consolidates, the crisis activates forgotten potentialities. That which I have elsewhere termed the imagination of crisis provides the surprisingly fertile cultural ground in which American resilience takes root ${ }^{4}$.

6 Our present times have elicited similar reflexes. The catastrophe of September 11 was not detached from its American context, was not a sudden irruption into the American world of some unknown temporalities. As Vincent Michelot has argued ${ }^{5}$, the American political landscape was already mired in a deep malaise prior to September 11, due in part to tension at the core : Dick Cheney and Donald Rumsfeld had a reformist agenda to « re-imperialize » the Presidency, but the presidential legitimacy of George W. Bush was weak; he had taken office under hotly contested circumstances and his political initiatives (a Reagan-like tax-reduction program and education reforms) were unpopular. Without legitimating the brand of revisionist hypothesis that casts doubt on the authenticity the World Trade Center attacks, it is impossible not to acknowledge that the Bush administration managed, just as happened in the time of the Pilgrim Fathers, to exploit dramatic events by emphasizing their tragic character. In a newly rediscovered religious vein, the New York towers' collapse became the antitype of the biblical destruction of Babel. This was a warning to an America numbed by vanity and lured into overconfidence by the mirage of the end of history. The attacks were a providential opportunity for yet another archetypically American refounding. And so the «imperial » presidency did, for a while at least, rediscover the fount of its legitimacy.

7 The American perception of temporality has at times given way to grievous misapprehensions. In 2009, at the beginning of the trial of Khalid Shaikh Mohammed, the mastermind behind the September 11 attacks, The New York Times reported that he had spent a number of years studying at American universities and that it was the knowledge of the United States he had gained during that time that had provided him with the legitimacy necessary within Al-Qaeda ranks to carry out his plan to use passenger airliners as flying bombs ${ }^{6}$. His intention was to shock the American public into a realization of the damages that American hegemony had inflicted on the wider world. But, to his great surprise, it would seem, the eventual reaction was not what he hoped for - he had not imagined that a traumatized America would plunge headlong 
into renewed imperialism. As we now know, the American response was to launch the " war on terror ". This was not the first time that crisis gave way to aggressive backlash in the form of expansionist outburst: the crisis of 1837 was followed by war with Mexico, while the crisis that gripped the nation in 1893 gave way to conflict with Spain $^{7}$. America in crisis is transfigured - that is not to say that it no longer resembles itself but, rather, that it reveals its true face. And it is one of violent past, perpetuated in the present.

8 At the same time, Republican America does its best to downplay a crisis of another sort and one that has been looming well ahead of the present economic quandary: the climate and environment crisis. Some among the more fundamentalist movements have embraced an extreme, apocalyptic worldview ; for some religious groups, indeed, were the ecological disaster in fact to occur, it would be nothing else than the manifestation of divine design. After all, read literally, does not the biblical narrative lead to an end of time and last judgment, when the chosen will be called to sit at the side of God ? Apocalyptic fiction, such as Tim La Haye's and Jerry B. Jenkins' successful, multi-sequel franchise Left Behind: A Novel of the Earth's Last Days (1995), feeds on biblical interpretation, especially its most millenariarist implications, such as had at one time been the purview of Cotton Mather. In 2005, the devastation of hurricane Katrina, too, became a time to rethink foundations, this time those of New Orleans - a city perhaps a tad too European - and to reconstruct it in closer conformity with the standard model of the great American city. Though it may have seemed the end of days, the crisis is once again integrated into American temporality.

\section{From cyclical to systemic crisis : An America become unlike itself}

More recent times have been witness to the emergence of another type of cultural production, a new manifestation. The crisis no longer represents both the end and the beginning in the mythical " course of empire ", oscillating inevitably between creation and destruction. Rather, these more recent narratives denounce crises as the symptom of a quasi-viral chaos, one that propagates without need of a driving force external to itself. These crises, rather than reinforce the American dream, challenge its very founding principles. So much so, in fact, that America no longer resembles itself, because the crisis engenders the loss of the nation's very essence. Cormac McCarthy encapsulated the mood within the very title of his novel No Country for Old Men (2005), which, despite possible misinterpretations, does not tackle the pensions crisis.

Cormac McCarthy's attraction to stories rooted in Wild West violence is not new, going at least as far back as Blood Meridian (1985), a novel the author set against the backdrop of historical events unfolding during the American conquest of the West. More specifically, the story plays out during the United States' war with Mexico in the late 1840 s - precisely the type of episode of violent and expansionist outburst subsequent to major crises identified by Jean-Luc Tendil. In the book, a murderous posse takes advantage of a seemingly apocalyptic chaos to kill Apache Indians and Mexicans. This is a Hobbesian world, where man is a wolf to his fellow man. With a disturbing fascination, we follow the mysterious character of a judge who philosophizes on evil in between murders - not unlike a reincarnation of Joseph Conrad's Colonel Kurtz, from Heart of Darkness, a work rooted in the conscience of Belgian colonialism in Africa ${ }^{8}$. But 
in the American past, where the natural state of things was violence, the social contract was torn before it could be weaved. And, as Yvonne-Marie Rogez' analysis shows, America produces apocalyptic crises.

11 We are faced, thus, by an inextricable History of Violence. Yet, in his last two novels - No Country for Old Men (2005) and The Road (2006) - Cormac McCarthy has explored more humanist tangents. There is a connection to be drawn between this thematic turn and the vision that Walker Evans and James Agee had expressed several decades earlier in Let Us Now Praise Famous Men ${ }^{9}$, a work that exposed, in word and photograph, both the misery and the dignity of Alabama farming families during the Great Depression of the 1930s.

12 At the beginning of No Country for Old Men, the protagonist Llewelyn Moss, a hunter, comes across a murder scene and discovers a large sum of money. Though this is mere coincidence, it has definite consequences, as the hunter becomes a prey for Chigurh, a killer incarnating absolute evil. In this opening act, the narrator tells us that: « rocks there were etched with pictographs perhaps a thousand years old. The men who drew them hunters like himself. Of them there was no other trace » (McCarthy, 2005). Later on, this assessment turns out not to be entirely true, as Llewelyn also finds stones carved to serve as mortar bowls, where ancient inhabitants once ground their grain. There is continuity between this pre-Columbian heritage and the modern hunter's values, a configuration that goes at least as far back as James Fenimore Cooper. This quintessentially American dichotomy can be disconcerting from a European perspective : the hunter stands on the side of civilization, in opposition to the killer. Such continuity has survived many crises, but in the land of No Country for Old Men the generational, inter-ethnic, American, almost geological genealogy, is in peril. A genealogy of violence, yes, but an unmistakably American genealogy, an identity engraved in the land. Here as elsewhere, the figure of the hunter portends an endangered social contract, as it does also in Michael Cimino's seminal film depiction of the Vietnam War, The Deer Hunter (or, as the French translation has it, Journey to the End of Hell). Like Michael and his fellow hunter-soldiers in Cimino's film, McCarthy's Llewelyn Moss is a veteran of the Vietnam War.

13 Yet another character, that of the Sheriff, himself getting long in the tooth, meditates on the title theme throughout McCarthy's novel. It is through this character that the author unfolds his perspective onto a world confronted by inexorably advancing evil, as absolute as it was unforeseen. The Sheriff's folksy morality, which at times muddles good morals and good manners, can border on the comical : « any time you quit hearin Sir and Mam the end is pretty much in sight » he bemoans on the novel's closing page. But there are more worrisome omens, as well: his wife hears on the radio that an alarming proportion of young parents are becoming disinterested in the education of their children, many of whom are raised by grandparents. But what is going to happen when those children beget children in their turn and entrust them to grandparents who have lost their sense of child rearing, when intergenerational transmission will have been lost? The novel's epilogue consists of a dialogue between Sheriff Bell and Llewelyn's father ; Bell has come bearing the news of the hunter's death. The Vietnam theme surfaces once again, yet that crisis had been a moral one for Americans only because America's own social contract was broken. The human crisis of the novel is not one of declining morals. Through the Sheriff's character, McCarthy channels attitudes holding sway in the Southwestern United States today - drugs are the source of the 
evil: «I think if you were Satan and you were settin around tryin to think up something that would just bring down the human race to its knees what you would probably come up with is narcotics $»^{10}$. The drugs, the dirty money, the fortunes so colossal they could buy entire countries - therein lies the true menace.

Llewelyn's desperate flight leads him across the Rio Grande, a boundary frequently breached in McCarthy's frontier stories (notably in The Crossing ${ }^{11}$ ). While economists may analyze national policies and literary critics focus on language frameworks and distinct geocultural domains, McCarthy is interested in transboundary spaces: he knows they are porous and long have been so. His is a vision that unsettles customary perspectives onto American literary history and the construction of national consensus. American unity is confounded by this different kind of crisis. The theme of porous frontiers also pervades Russell Banks' novel, Continental Drift (1985) ${ }^{12}$, in which the deindustrialization of New England pushes a family of modest means to seek better fortunes in Florida; at the same time, the violence of Haiti's paramilitary Macoute troops impels a woman to take her chances among a group of boat-people, eventually coming ashore on the Floridian coast. Two uprootings, one convergence.

Parallel to this shift, there has been a palpable rise in the production of what we may term border films: contemporary variations on the Western. One demonstrative example is Tommy Lee Jones' The Three Burials of Melquiades Estrada, released during the same period that McCarthy's No Country for old Men was published ${ }^{13}$. It is a quintessentially transamerican and hemispheric undertaking, as much because of its subject matter, as because of its collaborative process, involving as it did Mexican screenwriter Guillermo Arriaga. The film is a modern, nostalgic Western, set in defense of values cast aside by George Bush's America, in which a border wall of exclusion had replaced a zone of mutual exchange and hybridization. This film, too, says that this country is no longer for some, but at stake here is a fundamental, dual uprooting. Melquiades Estrada is a Mexican agricultural worker in Texas, who frequently reminisces about his native home at Jimene ${ }^{14}$. Mike Norton is a young border patrolman, assigned to contain clandestine immigration along the Mexican border on a post far from his home. Mike personifies the dislocation and destabilization of young Americans surrounded by ambient violence : barely skilled but quick on the trigger, he kills Melquiades in a moment of confusion. Enter Melquiades' American friend, Pete Perkins, played by director Tommy Lee Jones. Once he locates the murderer, Pete forces Mike to transport Melquiades' decomposing body to Mexico, so that his friend can find rest in peace at Jimenez, the town of which he had always talked so wistfully.

These examples point to a metamorphosis in American narratives over the course of the past century. At the outset of the development curve, they served as a mechanism that made possible the integration of crises; the narrative fiction functioned as a kind of assimilation ritual, contributing to a process of adherence to the nation. By contrast, in the tradition enacted by Evans and Agee, the recent novels and films of the Southwestern frontier expose an insidious crisis: it is more fundamental, more systemic than previous challenges, and it incarnates a sense of debasement, a dispossession of identity. Crises, says this current in fiction, are not, not anymore, the driving force of an open, adaptive system that can draw benefits from crisis in order to evolve and adapt, to better perpetuate itself. The present global crisis challenges the systemic boundaries of the United States in an American continent that has become at once integrated and disintegrated to unprecedented degrees. 
17 As Kenneth Lincoln has noted in his recent reading of McCarthy's body of work, the author of No Country for Old Men exposes the flip side of what Americans call manifest destiny. Sheriff Bell's wife reads and re-reads the Apocalypse ; for Bell, the crisis will come plainly, inevitably. Perhaps because he feels that Americans never become fully adult. Like the protagonist in Blood Meridian, they remain adolescents, whether faced with the expansive transborder empire zones of drug barons or the overwhelmingly huge amounts of dirty money lying at the ready for anything to be bought. Or, for that matter, the grim menace of nuclear winter, as in McCarthy's The Road, a crisis from which civilization will not rise again, unless we count the quasi-Quixotic preservation of interindividual values, family attachment among them. American jeremiads persist in perceiving crises in every age. McCarthy, because he lacks faith in a chosen American people, is a radical pessimist - that which Cotton Mather could not have been without renouncing his faith. Yet McCarthy's readers and those who inhabit the Southwestern frontier border region know well that notwithstanding the more or less well-advised economic policies of the American and Mexican governments, the crises yet to come are germinating in the prodigious flows of drug money circulating along with the narcotraffic plague that saps the vitality of whole populations. What is more, the interminably reciprocated settling of accounts between traffickers and police has infected the land with a violence that now reaches far beyond the Colombian borders where la violencia first flowered. Today, the violence has a grave impact on the Southern United States, where firearms are come by all too easily. In addition, the generalized inertia that seems to greet the threats of global warming and nuclear proliferation does nothing to dispel the potential gloom of the post-apocalyptic winter, nuclear or otherwise, that will not make life very agreeable at all and which, in fact, will endanger not only human dignity, but the human race as a whole. American writers, Northern as well as Southern, have sounded the warning. It is a post-crisis world that will be no country for the old - or for the young.

\section{BIBLIOGRAPHIE}

Agee, James and Walker Evans, Let Us Now Praise Famous Men, Boston, Houghton-Mifflin, 1941.

Banks, Russell, Continental Drift, New York, Harper and Row, 1985.

Bercovitch, Sacvan, The Rites of Assent : Transformations in the Symbolic Construction of America, New York and London, Routledge, 1993.

Conrad, Joseph, « Heart of Darkness », in Youth and Other Stories, Blackwood's Magazine, 1902.

Cottret, Bernard, Lauric Henneton, Jacques Pothier \& Bertrand Van Ruymbeke (dir.), Naissances de l'Amérique du Nord, 1607-1776, Paris, Les Indes Savantes, 2008.

Faulkner, William, The Hamlet, New York, Random, 1940.

Henneton, Lauric, Liberté, Inégalité, Autorité : Politique, Société et Construction identitaire du Massachusetts au XVII ème siècle, Honoré Champion, 2009. 
Lincoln, Abraham, « Gettysburg Address », MyLOC, Library of Congress, http://myloc.gov/ exhibitions/gettysburgaddress/, page consulted on October $11^{\text {th }}, 2013$.

Lincoln, Kenneth. Cormac McCarthy: American Canticles, New York, Palgrave Macmillan, 2009.

Mather, Cotton, Magnalia Christi Americana : or, The Ecclesiastical History of New-England, From its First Planting, in the Year 1620, Unto the Year of Our Lord 1698 (2 volumes), Hartford, Silas Andrus and Son, 1853.

http://books.google.com/books?id=BfPPrhVaUcMC\&hl=fr\&pg=PA1\#v=onepage\&q\&f=false

Mazzetti, Mark, « 9/11 planner didn't fit the Qaeda mold», International Herald Tribune, 16 novembre 2009 , section 1, p. 6 .

McCarthy, Cormac, Blood Meridian or The Evening Redness in the West, New York, Random House, 1985.

McCarthy, Cormac, No Country for Old Men, New York, Vintage book, USA, 2005.

McCarthy, Cormac, The Crossing, New York, Knopf, 1994.

McCarthy, Cormac, The Road, New York, Knopf, 2006.

Michelot, Vincent, « Le 11 septembre 2001 : acte fondateur ou mythe fondateur ? » in Bernard Cottret, Lauric Henneton, Jacques Pothier \& Bertrand Van Ruymbeke (eds.) Naissance de l'Amérique du Nord: les actes fondateurs - 1607-1776, Les Indes savantes, 2008, p. 171-180.

Morin, Edgar, «Les Amériques face à la Crise : exposé », IdeAs [Online], n4, http:// ideas.revues.org/651, page consulted on October 7th, 2013.

Rogez, Yvonne-Marie, « Cormac McCarthy, Blood Meridian, Western de l'Apocalypse, Apocalypse du western », [en ligne] Cercles n 16-2, 2006, p. 134-140. http://www.cercles.com/n16/2/ rogez.pdf, page consultée le 11 octobre 2013.

Tendil, Jean-Luc, « Les crises aux États-Unis depuis 1837 : facteurs de renouveau et de redéploiement ", IdeAs [Online], $\mathrm{n}^{\circ} 4$, http://ideas.revues.org/685, page consulted on October 7th, 2013.

\section{NOTES}

1. On this period, see: Lauric Henneton (2009).

2. For an analysis of foundational events as positive crises in North American history, see Cottret, Henneton, Pothier \& van Ruymbeke, dir. (2008).

3. The text of Lincoln's address is the "standard text" inscribed on the Lincoln Memorial in Washington DC. The monumental quality of the document is considerable. See http://myloc.gov/ exhibitions/gettysburgaddress/ for an on-line exhibition of the collection preserved in the Library of Congress, including the reproduction of other drafts and their transcription.

4. A small, but significant anecdote : in William Faulkner's novel, The Hamlet, a child is baptized with the charming name of Wallstreet Panic by his poor parents with the hope that the name will lead him towards the same kinds of fortunes that financiers were able to amass during a recent crisis. In the novel's diegetic context, the crisis is that of 1893 , but the analogy's cathartic power lies in ambiguity, since Faulkner's readers in 1940 would naturally have related it to the Crash of 1929.

5. See Vincent Michelot (2008).

6. «For all his professed wisdom about the United States, Mohammed later admitted that he had completely misjudged what the U.S. response to the Sept. 11 attacks would be. He did not expect 
the military campaign in Afghanistan, nor the relentless hunt for Al-Qaida leaders throughout South Asia and the Middle East » (Mazzetti, 2009).

7. See Jean-Luc Tendil study in the present issue: «Les crises aux États-Unis depuis 1837 : facteurs de renouveau et de redéploiement ».

8. See Joseph Conrad (1899).

9. See Agee \& Evans (1941). Let Us Now Praise Famous Men started out as a documentary project where Evans (the photographer) and Agee (the writer) documented the life of three peasant family in the Alabama cotton-belt. As the biblical title suggests, what started as a social and economic report on the life-conditions of the Southern peasantry, commissioned by Fortune magazine, turned into a vibrant homage to the dignity of the common man, going far beyond the picturesque, superficial and often patronizing approach to this population.

10. See McCarthy (2005: 218).

11. See McCarthy (1994).

12. See Banks (1985).

13. Incidentally, Tommy Lee Jones also plays the disillusioned Sheriff Bell in the Coen brothers' film adaptation of No Country for Old Men (2007).

14. It is not difficult to perceive the character, a seasonal worker who has no fixed address, as a quiet tribute to Gabriel García Márquez : Melquiades was the name of the gypsy in One Hundred Years of Solitude. Another major inspiration was William Faulkner's As I Lay Dying : both the novel and the film take on the theme of a perilous voyage to bring a decomposing body to its troubled native land.

\section{RÉSUMÉS}

Les diverses crises qu'ont traversées les États-Unis au cours de la première décennie du siècle, de l'attaque du World Trade Center en 2001, à la catastrophe environnementale de Katrina, puis la crise financière qui a commencé en 2008 , nous rappellent que l'Amérique a toujours intégré des crises dans son récit, comme occasion pour démontrer sa résilience innée. Les romans les plus récents de Cormac McCarthy suggèrent que la violence contemporaine est un cran au-dessus, car elle déborde au delà des frontières et menace de remplacer une histoire pleine de violence par un chaos pré-apocalyptique. La littérature pointe ainsi des facteurs de déclin que les instruments de mesure des sciences sociales ne savent pas forcément totalement prendre en compte.

The various crises the United States went through over the first decade of the century, from the attack on the World Trade Center in 2001, the environmental disaster of Katrina to the financial crisis that started in 2008, remind us that America has always integrated crises in its narrative, as an opportunity for demonstrating its in-bred resilience. Cormac McCarthy's later novels suggest that the contemporary violence goes one step beyond, as it spreads beyond borders and threatens to replace a history of violence by pre-apocalyptic chaos. Literature thus points at the factors of decay that the instruments of the social sciences are not necessarily trained for.

Las distintas crisis que atravesaron los Estados Unidos durante la primera década de este siglo, del ataque del World Trade Center en 2001, a la catástrofe medioambiental de Katrina, y la crisis financiera que comenzó en 2008, nos recuerdan que América siempre ha integrado la crisis en su relato, como otra ocasión de demostrar su resiliencia inata. Las novelas más recientes de Cormac 
McCarthy sugieren que la violencia contemporánea es una muesca encima, ya que desborda más allá de las fronteras y amenaza con sustituir una historia llena de violencia por un caos preapocalíptico. La literatura señala así factores de decadencia que los instrumentos de medida de las ciencias sociales no saben tener completamente en cuenta.

\section{INDEX}

Keywords : American literature, Cormac McCarthy, apocalyptic, border literature, cinema Mots-clés : littérature américaine, Cormac McCarthy, apocalyptique, cinéma, frontière Palabras claves : literatura americana, Cormac McCarthy, apocalíptico, literatura de la frontera, cine

\section{AUTEUR}

\section{JACQUES POTHIER}

Jacques Pothier teaches American literature at the Université de Versailles Saint-Quentin en Yvelines, where he is the director of the research center « Suds d'Amériques » and assistant dean of the Institute for Languages and International Studies. He is a vice-president of the Institut des Amériques (France). He has published two books, William Faulkner : essayer de tout dire (Paris, Belin, 2003) and Les nouvelles de Flannery O'Connor (Nantes, France, Le Temps, 2004). His fields of research cover the literature of the South, interactions between the literature and history of the South and Latin-American literature, modernism and post-modernism, literature and the visual arts, the theme of space, the epistemology of American Studies, the role of literature in the construction of ethnic, local or national identities and as privileged field for cultural transfer. He is involved in the edition of the works of William Faulkner in la Pléiade, Gallimard. jacques.pothieratgmail.com 